Fernanda Trombini Rahmen Cassim

Universidade Estadual de Maringá**

\title{
COHERENCE RELATIONS IN ACADEMIC SPOKEN DISCOURSE
}

\section{INTRODUCTION}

Since the beginning of the studies about language, spoken language has been treated in three different ways according to Chafe (1994). First, in the Classical Grammatical Tradition started by the Greeks and disseminated by the Romans, oral language was not granted the same prestige as was written language. With the outbreak of Linguistics, especially American Structural Linguistics, the importance given to the description of languages without written tradition raised spoken language to the status of linguists' real study object. Over the last decades, however, a more balanced view of oral and written language has become common. According to this view, both spoken and written language are distinct realizations of language, but with different functions. Corroborating this view, Neves (1996) remarks that spoken language and written language share the same grammar system, but are different regarding production, transmission and reception methods, let alone organizational structures.

A mistake constantly made when comparing spoken and written language is to conceive them as completely opposed. Ochs (1979) supports the idea that spoken and written language may be considered a continuum depending on the level of planning. This author suggests four levels of planning: non-planned spoken discourse, planned spoken discourse, non-planned written discourse and planned written discourse. Thus, a note written on the rush may have much more similarities with an informal storytelling (oral) than with the editorial of a newspaper (written). On the other hand, the newspaper editorial might share much more characteristics with a formal speech to an audience than with the on-the-rush written note. Marcuschi (2000) also criticizes the dichotomic view towards spoken/written language distinction. According to this Brazilian linguist, this view usually conceives written discourse as more elaborate and complex than spoken discourse.

Another mistake is to analyze texts of different genres or types and assign the differences to spoken and written language. The researcher chooses spoken texts of one genre or type and written texts of different types or genres. According to Tannen

\footnotetext{
* Author's address: Departamento de Letras, Av. Colombo, 5790, Campus Universitário, CEP 87020900 Maringá, Brazil. Email: jdantonio@uem.br

** Author's address: Departamento de Letras, Av. Colombo, 5790, Campus Universitário, CEP 87020 900 Maringá, Brazil. Email: fer_trc_@hotmail.com
} 
(1982), most of the differences which arise in this case are triggered by differences regarding text types or genres and not spoken/written language.

In this paper, ${ }^{1}$ we claim that some intrinsic spoken discourse phenomena like paraphrasing, correction, repetition and parenthetical insertion hold coherence relations with other portions of discourse and, thus, may be considered strategies for the construction of coherence in spoken language. According to Rhetorical Structure Theory (henceforth RST), implicit propositions emerge from the combination of pieces of text which hang together. Various authors have labeled implicit propositions as coherence relations, discourse relations, rhetorical relations or relational propositions. When two portions of a text hold a relation, the addressee of the text may recognize the connection even without the presence of a formal sign as a conjunction or a discourse marker. Thus, this paper also aims at investigating how these relations are established linguistically.

\section{Theoretical background}

\section{RST}

RST is a descriptive theory whose object of study is the organization of texts, characterizing the relations established among parts of texts (Mann and Thompson 1988). According to RST, besides explicit propositional content conveyed by the clauses of a text, there are implicit propositions (called relational propositions) which arise from the relations held between text spans (Mann and Thompson 1983). Matthiessen and Thompson (1988) state that relational propositions permeate the whole text, from relations established between text spans to relations established between two clauses. RST assumes that these relations are essential to the coherence of the text (Mann and Thompson 1988), as they confer unity to the text and enable the producer of the text to reach the aims that the text was intended to.

Relational propositions receive other labels such as "discourse relations", "coherence relations" or "rhetorical relations" (Taboada 2009: 127). Regarding organization, relations can be of two types:

- nucleus-satellite (hypotactical), in which satellite is ancillary to the nucleus. This type of organization is represented in figure 1: an arch goes from satellite to nucleus.

multinuclear (paratactical), in which a text span is not ancillary to the other. Each span is a distinct nucleus, as in figure 2 .

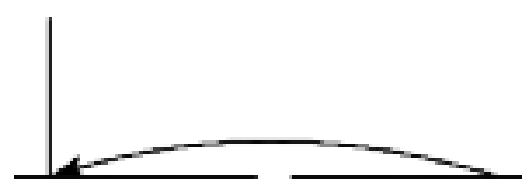

Figure 1: Nucleus-satellite schema.

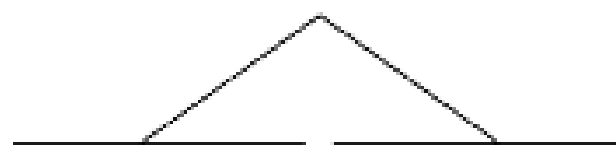

Figure 2: Multinuclear schema.

\footnotetext{
${ }^{1}$ The research was supported by Fundaçăo Araucária (Contract 939/2012 - UEM - Fundaçăo Araucária).
} 
Rhetorical relations are defined by RST based on four criteria: a) constraints on the nucleus; b) constraints on the satellite; c) constraints on the nucleus-satellite combination; d) effect. According to Gómez-González and Taboada (2005), RST has a bias towards the text producer. Thus, the most important characteristic in relation definition is the effect that the discourse producer wants to achieve in his/her addressee.

Let us take as examples the definitions of elaboration, preparation (nucleus-satellite relations) and contrast and sequence (multinuclear relations) in tables 1 and 2.

\begin{tabular}{|c|c|c|c|}
\hline Relation name & $\begin{array}{l}\text { Constraints on either } \\
\mathrm{S} \text { (satellite) or } \mathrm{N} \\
\text { (nucleus) individually }\end{array}$ & Constraints on $\mathrm{N}+\mathrm{S}$ & $\begin{array}{l}\text { Intention of } \\
\text { Speaker/Writer }\end{array}$ \\
\hline Elaboration & None & $\begin{array}{l}\text { S presents additional } \\
\text { detail about the situation } \\
\text { or some element of } \\
\text { subject matter which is } \\
\text { presented in } \mathrm{N} \text { or } \\
\text { inferentially accessible in } \\
\mathrm{N} \text { in one or more of the } \\
\text { ways listed below. In the } \\
\text { list, if } \mathrm{N} \text { presents the first } \\
\text { member of any pair, then } \\
\mathrm{S} \text { includes the second: } \\
\text { set :: member } \\
\text { abstraction :: instance } \\
\text { whole :: part } \\
\text { process :: step } \\
\text { object :: attribute } \\
\text { generalization :: specific }\end{array}$ & $\begin{array}{l}\text { Addressee } \\
\text { recognizes } \mathrm{S} \text { as } \\
\text { providing additiona } \\
\text { detail for } \mathrm{N} \text {. } \\
\text { Addressee identifies } \\
\text { the element of } \\
\text { subject matter for } \\
\text { which detail is } \\
\text { provided. }\end{array}$ \\
\hline Preparation & None & $\begin{array}{l}\mathrm{S} \text { precedes } \mathrm{N} \text { in the text; } \\
\mathrm{S} \text { tends to make the } \\
\text { addressee more ready, } \\
\text { interested or oriented for } \\
\text { reading } \mathrm{N}\end{array}$ & $\begin{array}{l}\text { Addressee is more } \\
\text { ready, interested or } \\
\text { oriented for } \\
\text { reading/hearing } \mathrm{N}\end{array}$ \\
\hline
\end{tabular}

Table 1: Definition of elaboration and preparation nucleus-satellite relations (Mann and Taboada, 2010).

\begin{tabular}{|l|l|l|}
\hline Relation name & Constraints on each pair of N & Intention of Speaker/Writer \\
\hline Contrast & $\begin{array}{l}\text { No more than two nuclei; the situations } \\
\text { in these two nuclei are (a) compre- } \\
\text { hended as the same in many respects (b) } \\
\text { comprehended as differing in a few re- } \\
\text { spects and (c) compared with respect to } \\
\text { one or more of these differences. }\end{array}$ & $\begin{array}{l}\text { Addressee recognizes the com- } \\
\text { parability and the difference(s) } \\
\text { yielded by the comparison is } \\
\text { being made. }\end{array}$ \\
\hline Sequence & $\begin{array}{l}\text { There is a succession relationship } \\
\text { between the situations in the nuclei. }\end{array}$ & $\begin{array}{l}\text { Addressee recognizes the } \\
\text { succession relationships among } \\
\text { the nuclei. }\end{array}$ \\
\hline
\end{tabular}

Table 2: Definition of contrast and sequence multinuclear relations (Mann and Taboada, 2010). 
A list of 25 relations was initially suggested by Mann and Thompson (1988) after the analysis of hundreds of texts with RST. Afterwards an extended version of this list has been provided at RST website (http://www.sfu.ca/rst/01intro/definitions.html). However, this list is not a closed one, and other relations can be defined according to the investigated type or genre of text.

Rhetorical relations can also be classified whether they are subject matter or presentational. The intended effect of subject matter relations is that the addressee recognizes the relation in question, as in elaboration relation, while the intended effect of presentational relations is to increase some inclination in the addressee, such as the desire to act or the degree of positive regard for, belief in, or acceptance of the nucleus, as in preparation relation.

The identification of the relations by the analyst is based on functional and semantic judgments, seeking to identify the function of each text span and to investigate how text produces the desired effect on its possible addressee. These judgments are of plausibility, since the analyst has access to the text, is aware of the context in which the text was produced and of the cultural conventions of the text producer and its possible addressees, but has no direct access to the text producer or to its possible addressees. Hence, the analyst cannot say with certainty whether this or that analysis is correct, but may suggest a plausible analysis (Mann and Thompson 1988).

Two mistakes must be avoided by analysts. One of them is relying only on the form of the text. According to Mann and Thompson (1988), RST structures are structures of function, and not structures of form. In example (1), connective $e$ (and), a typical additive conjunction, is used to establish a purpose relation. The example is from a psychology class, and the professor is telling the students to teach their subject (a lab mouse) to emit a response with the purpose of being rewarded with a drop of water. Thus, the plausible analysis for this example is that a purpose relation, and not an additive relation, is established between the clauses.

(1) Nós vamos ensinar o nosso sujeito a emitir a resposta de pressão à barra, e receber uma gota de água.

We're going to teach our subject to emit a pressure response to the bar, and receive a water drop.

Another problem is conceiving that only discourse markers can signal relations. After investigating conversations and newspaper articles, Taboada (2006) concluded that a high number of rhetorical relations are not signalled. This author (2009) also presents some other mechanisms which can signal relations, like verb tense, sentence mood, embedding, verb meaning and implicatures. Reasearching contrast relation in interaction, Ford (2000) remarked that the meaning of the text spans can also be useful in identifying the relation. 


\section{METHODOLOGY}

The research corpus of this paper consists of five university lectures in Brazilian Portuguese of about 80 minutes long each. Subjects are university professors and the lectures present a formal register.

Other features that can be noticed on the lectures are speakers' roles and conversational turns previously determined (Koch and Souza e Silva 1996). Thus, there are few interaction signals, as the professor keeps the conversational turn most of the time. There are few interruptions from the audience for querying. These lectures also have a well-marked beginning with the presentation of the aims of the class, as well as a closure in which the topics of the next class are anticipated, as in examples (2) and (3).

(2) Então hoje eu vou estar passando para vocês o relatório que vai ter que ser feito, é o trabalho que vocês vão ter que fazer agora com os dados que foram coletados, tá?

So today I will be assigning to you the report that will have to be done, It's the paper that you will have go write now with the data that was collected, ok?

(3) E pra isso é primordial nós estudarmos o comportamento biológico da suspensão, a reologia da suspensão.

O que é isso?

Nós vamos deixar pro próximo capítulo, pra próxima aula, tá?

$\mathrm{Ah}$, gente, eu tava esquecendo,

Ó, presta atenção só um pouquinho:

As suspensões eu mandei pra vocês por e-mail os slides.

Aqui tem o roteiro da aula, o programa da aula, e tem xerox: são quatro, cinco capítulos de livros modernos sobre suspensões.

And for this it is very important that we study the biological behaviour of suspensions, the rheology of suspensions.

What's this?

We'll leave for the next chapter, for the next class, ok?

Oh, people, I was forgetting.

Look, pay attention a little.

The suspensions I sent to you via e-mail the slides.

Here is the guide of the class, the class programme, and there are photocopies: they are four, five chapters of modern books about suspensions.

The lectures were transcribed alphabetically and segmented into intonation units, defined by Chafe (1988: 1-2) as "brief spurts of vocalization" characterized by a single coherent intonation contour with a clause or sentence final intonation, usually separated by pauses and generally with a clause-like structure.

\section{ANALYSIS}

\section{Correction and paraphrasing}

Correction and paraphrasing may be mixed up, as both phenomena have the feature of discourse reformulation. However, according to Fávero, Andrade and Aquino 
(2006a), in correction one of the text spans is considered wrong and must be replaced, as in figure 3 below.

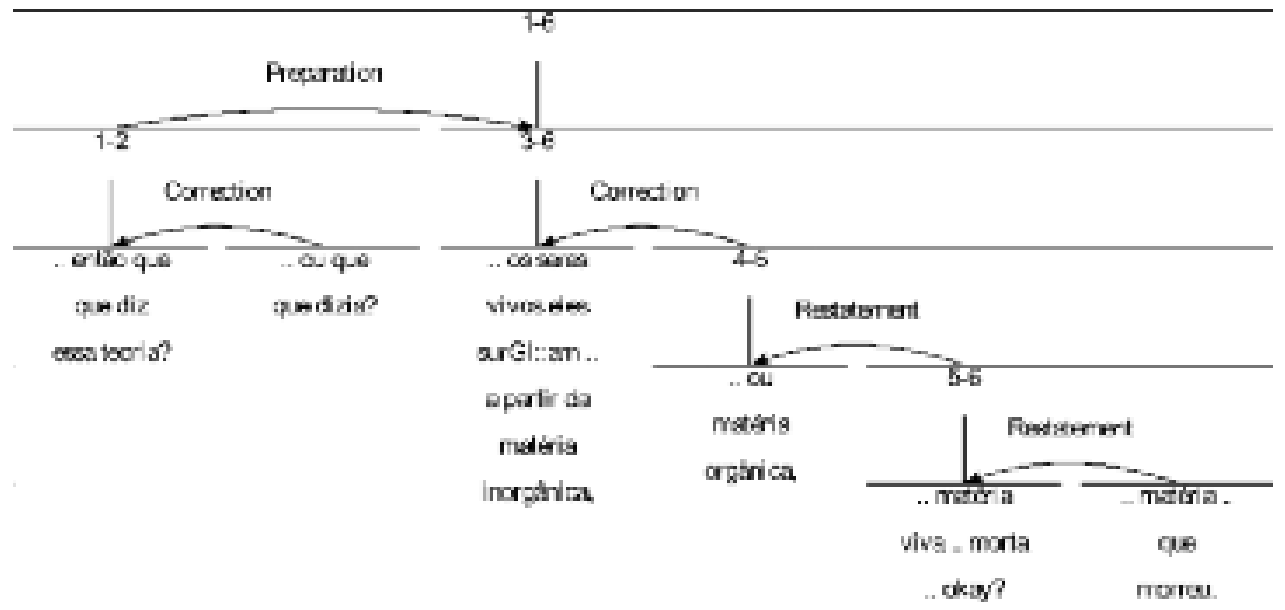

Figure 3: Rhetorical structure of text spans holding correction and restatement relations.

1 .. so what does this theory say?

2 .. or what did it use to say?

3 .. the living beings they appeared from inorganic matter,

4 .. or organic matter,

5 .. dead .. living matter, ok?

6 .. matter .. that died.

The example in figure 3 was taken from a Biology lecture in which the professor was talking about a theory which is not accepted by scientists any longer. In units 1 and 2, when he notices that he had used the verb "dizer" (to say) in the present tense ("diz" - say), he sees the need to correct himself and reformulates his question with the verb in the past tense ("dizia" - used to say). In unit 3, he says that life had come into being from inorganic matter, when he actually means organic matter. In unit 4 he corrects himself. In both cases, the speaker uses the connective "ou" (or) to introduce the correction.

There is not correction relation in RST. However, such a relation is necessary when analyzing non-planned spoken discourse. As spoken language is not editable (Chafe, 1985), speakers need to point it out when they made a mistake and state correctly what they meant. Thus, correction should be a presentational relation, as the intended effect is to have the addressee replacing the information previously mentioned by the last information.

On the other hand, in paraphrasing, the speaker uses previous discourse as the matrix for the new utterance. According to Fávero, Andrade and Aquino (2006a), there must be semantic equivalence between the matrix utterance and the paraphrase. 
In diagram 1, the professor paraphrases the expression "matéria orgânica" (organic matter, unit 4) twice (units 5 and 6) in order to explain to the students what organic matter is. In RST, restatement relation is used by speakers with the intention of having the addressee recognize S as a restatement of N. According to Hilgert (2006), paraphrasing helps the speaker find the most appropriate word or expression for what they mean, and this may be very useful in lectures and classes.

\section{Repetition}

Repetition is another important strategy used by speakers in order to organize their discourse and grant coherence. According to Marcuschi (2006), although it might seem that repetition might harm topic progression, it actually builds cohesion and topic continuity.

In figure 4, taken from a Geography lecture, repetition is expressed by means of syntactic parallelism. The lecturer talks about migrations in Brazil motivated by economic development. He states that if the economy was developing in the Northeast ("nordeste") of the country, people would move to that region. And the same question-answer structure is repeated for the other regions: North ("norte"), Center ("centro"), South ("sul"), Southeast ("sudeste").

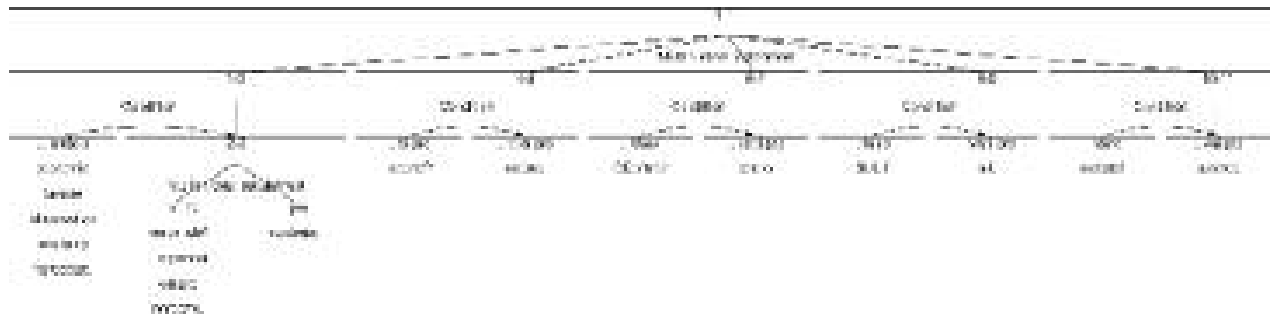

Figure 4: Rhetorical structure of text spans holding multinuclear-restatement relation.

1 .. so the economy was developing in the Northeast?

2 .. oh:: in the Northeast? .. people go to the Northeast,

3 .. to the Northeast.

4 .. developing in the North?

5 .. go North.

6 .. developing in the Center?

7 .. go to the Center.

8 .. developing in the South?

9 .. go South.

10 .. developing in the Southeast?

11. go Southeast.

In RST, the difference between nucleus-satellite restatement and multinuclear restatement is that in the last one there is no focus on any of the repeated spans, all the nuclei have the same status (Mann and Taboada, 2010). On the other hand, in figure 3, it is clear that one of the nuclei is more central to the purposes of the speaker, and he explains the content of the nucleus in other words by means of paraphrasing. 
The example of repetition in figure 5 is slightly different. While in figure 4 a discourse structure (question-answer pattern) is repeated with the change of a lexical item, in figure 5 the same verb form "manipular" (manipulate) is restated in units 2 to 5. There seems to be an iconic motivation for the repetition of the verb form, as its reiteration suggests that the manipulation of the soy seed had some duration. Sequence relation is held on the higher level of the rhetorical structure of the span in figure 5 as there is a chronological succession among the actions in the nuclei.

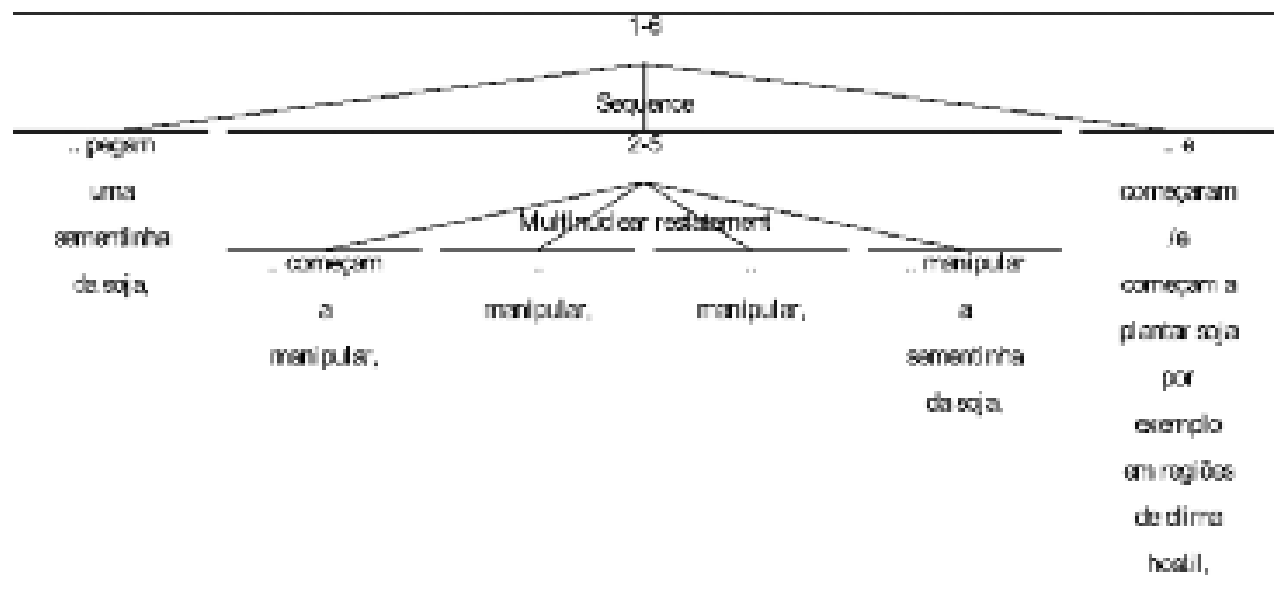

Figure 5: Rhetorical structure of text spans holding multinuclear-restatement relation.

1 .. they take a small seed of soy,

2 .. they start to manipulate,

3 .. manipulate,

4 .. manipulate,

5 .. manipulate the small soy seed,

6 .. and started / and started to plant seed for example in hostile climate regions,

\section{Parenthetical insertion}

According to Jubran (2006), parenthetical insertions are a detour of the discourse topic. They bring parallel information about the content of the discourse topic, about the linguistic expression of the discourse topic or about the communicative context. Although parenthetical insertions might seem diversionary regarding the discourse topic, they are actually bound to the topic as they bring information which is considered by the speaker essential to the understanding of the subject matter.

In figure 6, the lecturer is talking about the first organisms on Earth. He asks the audience whether they were autotrophic or heterotrophic (units 1 and 2). As the lecturer might not be sure whether the audience knows the meaning of these words, this discussion is paused while he explains what autotrophic and heterotrophic organisms are. The span in which this explanation is given is a parenthetical satellite in relation to the nucleus. Parenthetical relation is not among the relations initially defined by Mann and Thompson (1988), but it was defined later. Pardo (2005) states that the ef- 
fect of the relation is that the addressee recognizes that $\mathrm{S}$ presents extra information regarding $\mathrm{N}$, complementing $\mathrm{N}$. In figure 6 , the speaker announces the parenthetical relation by explicitly saying "parentêses" (parentheses).

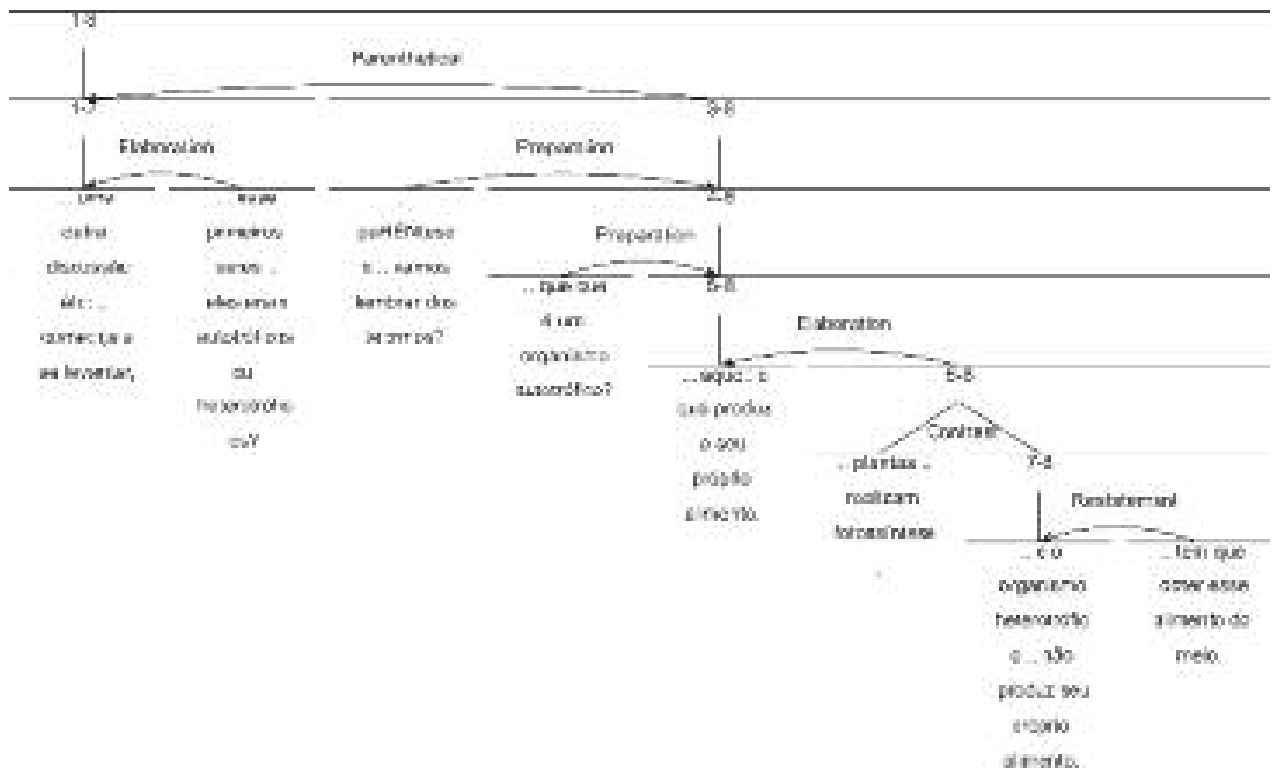

Figure 6: Rhetorical structure of text spans holding parenthetical relation.

1 .. another discussion éh:: .. starts to raise,

2 .. these first beings .. were they autotrophic or heterotrophic?

3 .. parentheses .. let's remember the terms?

4 .. what is an autotrophic organism?

$5 .$. the one that produces its own food.

6 .. plants make photosynthesis,

7 .. and the heterotrophic organism does not produce its own food,

8 .. it must obtain this food from the environment.

In figure 6 other relations are also used by the lecturer, as the preparation and the elaboration relations. The preparation relation is used by the speaker in order to make the addressee more interested, more ready or more interested in reading/hearing $\mathrm{N}$ (Mann and Taboada 2010), as in units 3 and 4 in figure 6. It is usually expressed by means of rhetorical questions. According to Fávero, Andrade and Aquino (2006b), the speaker does not expect an answer from the addressee. Actually, the answer is given by the speaker him/herself, but he/she uses the rhetorical question in order to introduce a new discourse topic or a new referent in discourse. The elaboration relation is used in order to present additional information about the subject matter of the nucleus. Unit 2 is an elaboration satellite which presents the discussion mentioned in unit 1 , and the span formed by units 6-8 presents information about how heterotrophic organisms produce their own food. 
In figure 7, the lecturer is explaining an experiment conducted by Italian biologist Francesco Redi. A purpose initial clause (unit 1) is used by the professor in order to state that Francesco Redi needed to prove his experiment. According to Thompson (1985), initial purpose clauses have a discourse function: they anticipate a problem and the solution to the problem is presented in the nuclear clause. In the example of figure 7, the problem is proving the experiment and the solution is the nucleus of the relation (units 4-6), a series of actions which happen in succession: he went there, put another plate with the same meat and covered it with a very thin piece of gauze. The parenthetical relation is held between units 2-3 and 1-3 by means of an explanation construction introduced by conjunction "que" (which would be short for because). Although unit 2 is introduced by "quando" (when), a condition relation is held inside the explanation construction. According to Neves (2000), this may happen when states-of-affairs of the time adverbial clause and of the main clause are simultaneous, aspect is non-perfective, implying iteration (when = every time), besides a habitual state-of-affairs that can be fulfilled by the conditions of the adverbial clause.

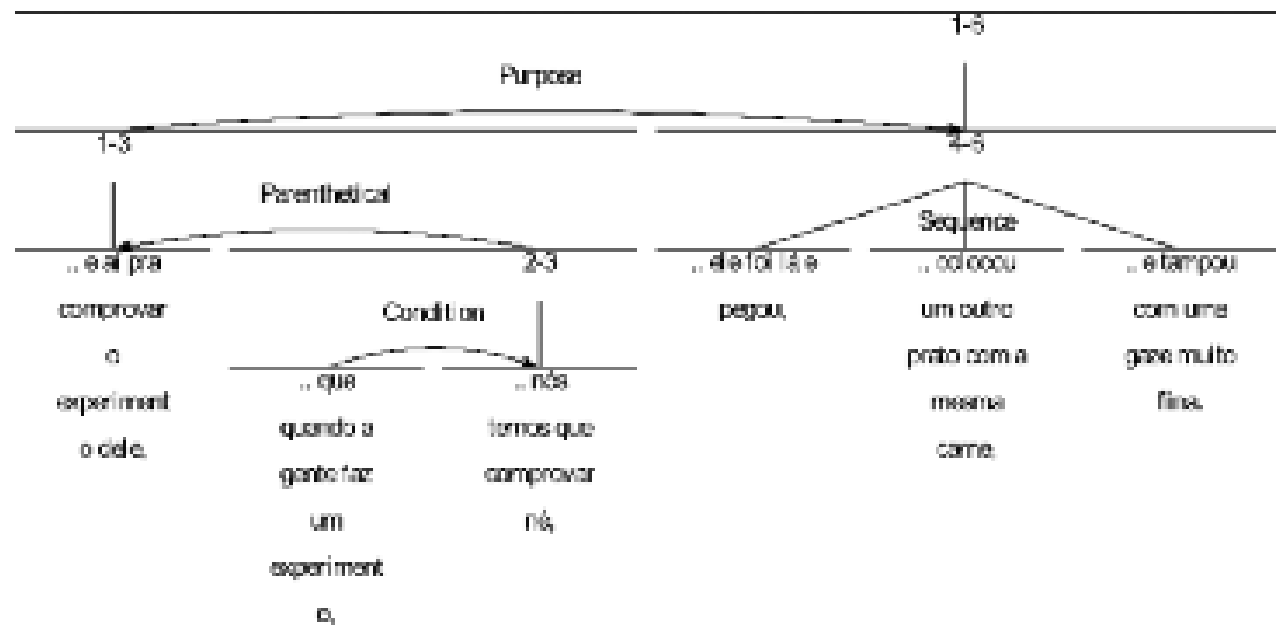

Figure 7: Rhetorical structure of text spans holding parenthetical relation.

$1 .$. and then to prove his experiment,

2 .. cause when we make an experiment,

3 .. we have to prove it, right?

4 .. he went there,

5 .. put another plate with the same meat,

6 .. and covered it with a very thin piece of gauze.

In figure 8 , the lecturer is talking about the appearance of the first organic molecules on Earth by means of peptidic links. He considers that the audience might not remember what peptidic links are and defines peptidic links before continuing his explanation. A parenthetical relation is held between the satellite in which the definition 
is given (units 2-5) and the nucleus (unit 1). The parenthetical relation is marked by conjunction "mas" (but) and a speech act purpose clause. In the example, "mas" does not have opposition of contrast meaning. It is used as a discourse marker to signal the parenthetical insertion. And a speech act purpose clause has, according to Thompson (1985), an illocutionary force that modifies the assertion made by the following material, and not the material itself. In other words, the lecturer uses the parenthetic insertion in order to bring to the memory of the audience what peptidic links are. The insertion is finished by a conclusion relation (unit 6) before the lecture resumes the topic that was being developed.

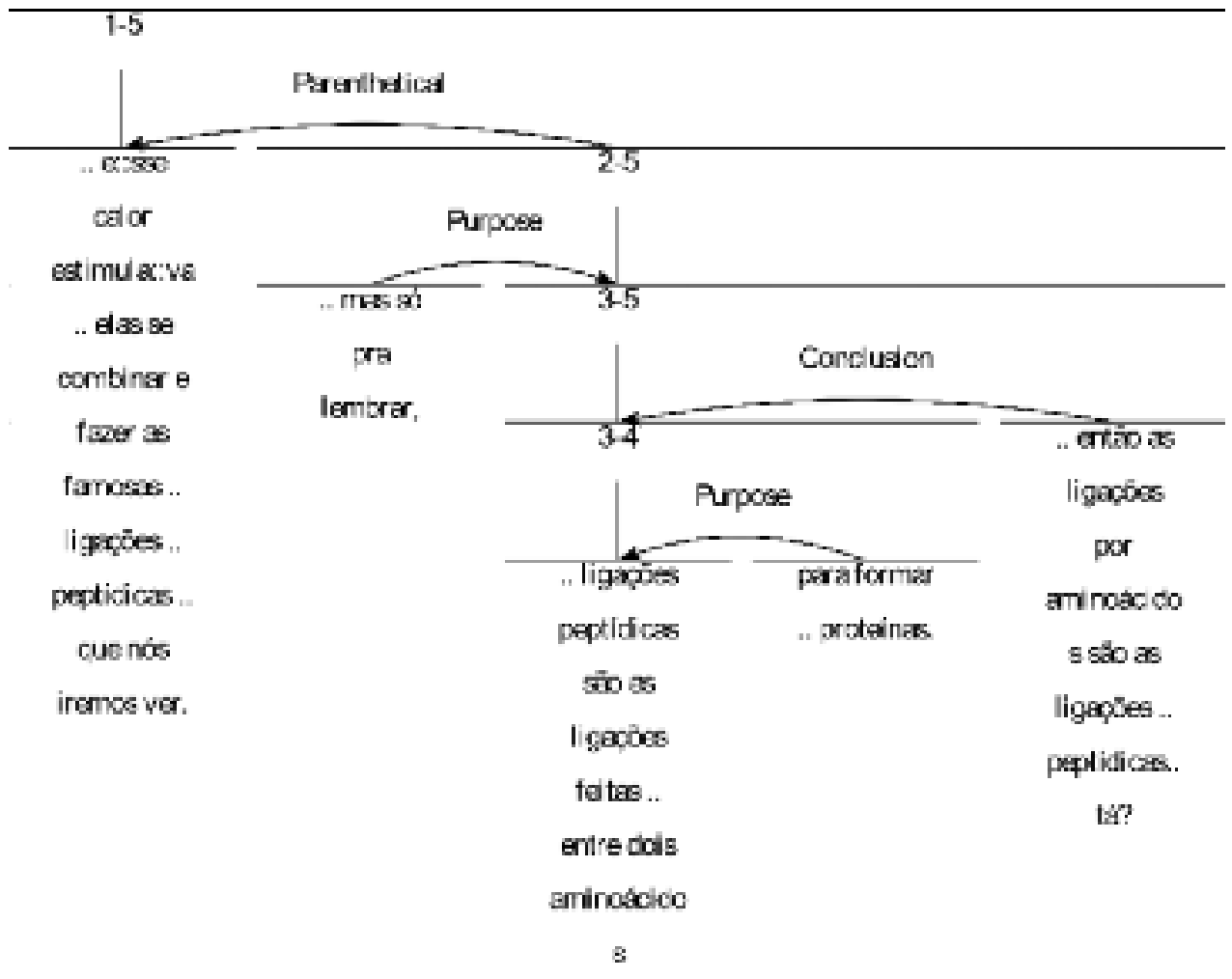

Figure 8: Rhetorical structure of text spans holding parenthetical relation.

1 .. this heat stimulated .. them to combine and make the famous .. peptidic .. links .. that we will see.

2 .. but just to remember,

3 .. peptidic links are the links made .. between two amino acids

4 .. to make proteins.

5 .. then links by amino acids are the peptidic links, ok? 


\section{Conclusion}

In this paper we attempted to show that some intrinsic spoken discourse phenomena like paraphrasing, repetition, correction and parenthetical insertion hold coherence relations with other portions of discourse and, thus, may be considered strategies for the construction of coherence. The framework used for the analysis was RST, a descriptive theory whose object of study is the organization of texts, characterizing the relations established among parts of texts. Examples were taken from academic spoken discourse (five university lectures in Brazilian Portuguese). The investigated phenomena are recurring in the corpus and, thus, are relevant for the study of spoken discourse.

Correction and paraphrasing are reformulation strategies. As spoken discourse is not editable, speakers need to correct something they may have failed to say appropriately or they may need to say something in other words in order to be understood by addressees. It was suggested that a correction relation should be created for RST list of relations. On the other hand, nucleus-satellite restatement relation was used to signal paraphrasing.

Repetition is important for topic continuity as it is possible for the speakers to show similarities between states-of-affairs by using syntactic parallelism. Repetition may also signal reiteration of a state-of-affairs. Multinuclear-restatement relation was used to signal repetition.

Finally, parenthetical insertions are essential for the coherence of spoken discourse. Speakers do not have the possibility of going back in time to provide information that should have been given as background before stating something. Thus, parenthetical insertions are used to 'pause' the development of the discourse topic and provide the information before the flow of information of the discourse topic is resumed. Although parenthetical relation did not exist in RST original list of relations, it was defined posteriorly.

\section{References}

CHAFE, Wallace (1985) "Linguistic differences produced by differences between speaking and writing." In: D. R. Olson et al. (eds), The nature and consequences of writing. Cambridge: Cambridge University press, 105-123.

CHAFE, Wallace (1988) "Linking Intonation Units in Spoken English." In: J. Haiman/S. Thompson (eds), Clause combining in grammar and discourse. Amsterdam/Philadelphia: Benjamins, 1-27.

Chafe, Wallace (1994) Discourse, Consciousness and Time. The flow and displacement of conscious experience in speaking and writing. Chicago: University of Chicago Press.

Fávero, Leonor L./Maria L. C. V. O. Andrade/Zilda G. O. Aquino (2006a) "Correção.” In: C.C.A.S. Jubran/I.G.V. Koch (eds), Gramática do Português Culto Falado no Brasil. Campinas: Editora da UNICAMP, 255-273.

FÁvero, Leonor L./Maria L. C. V. O. ANDrade/Zilda G. O. Aquino (2006b) "O par dialógico pergunta-resposta.” In: C.C.A.S. Jubran/I.G.V. Koch (eds), Gramática do Português Culto Falado no Brasil. Campinas: Editora da UNICAMP, 133-166. 
FORD, Cecilia (2000) "The treatment of contrasts in interaction." In: E. CouperKuhlen/B. Kortmann (eds), Cause, Condition, Concession, and Contrast: Cognitive and Discourse Perspectives, 283-312. Berlin: Mouton de Gruyter, 283-310.

Gómez-GonZÁles, María L. A./Maite TABOADA (2005) "Coherence Relations in Functional Discourse Grammar.” In: J. L. Mackenzie/M. L. A. Gómez-González (eds), Studies in Functional Discourse Grammar. Berne: Peter Lang, 227-259.

Hilgert, José G. (2006) "Parafraseamento." In: C. C. A. S. Jubran/I. G. V. Koch (eds), Gramática do Português Culto Falado no Brasil. Campinas: Editora da UNICAMP, 255-273.

Jubran, Clelia C. A. S. (2006) "Parentetização." In: C. C. A. S. Jubran/I. G. V. Koch (eds), Gramática do Português Culto Falado no Brasil. Campinas: Editora da UNICAMP, 275-300.

Koch, Ingedore G. V./Maria C. P. SouZa E SiLva (1996) "Atividades de composição do texto falado: a elocução formal." In: A. T. Castilho/M. Basílio (eds), Gramática do Português Falado. Campinas, Editora da UNICAMP, 379-410.

Mann, William C./Sandra A. Thompson (1983) "Relational propositions in Discourse." ISI/RR 83/115, 1-28.

ManN, William C./Sandra A. Thompson (1988) "Rhetorical Structure Theory: toward a functional theory of text organization." Text 8/3, 243-281.

ManN, William C./Maite TABoAda (2010) RST Web Site. 01 May 2012. http://www.sfu.ca/rst/.

MARCUSCHI, Luiz Antonio (2000) Da fala para a escrita: atividades de retextualização. S. Paulo: Cortez.

MarCuschi, Luiz Antonio (2006) "Repetição." In: C. C. A. S. Jubran/I. G. V. Koch (eds), Gramática do Português Culto Falado no Brasil. Campinas: Editora da UNICAMP, 219-254.

NEves, Maria H. M. (1996) "Reflexões sobre a investigação gramatical: projeto GPF grupo Sintaxe I." In: M.B.M Abaure/A. C. Rodrigues (eds), Atas do $1^{\circ}$ Congresso Internacional da Abralin. Salvador: Abralin, 421-427.

Neves, Maria H. M. (2000) Gramática de usos do português. S. Paulo: Editora da Unesp.

Ochs, Elinor (1979) "Planned and unplanned discourse." In: T. Givón (ed), Syntax and semantics 12: Discourse and syntax. New York: Academic Press. 51-80.

Pardo, Thiago A. S. (2005) Métodos para Análise Discursiva Automática. Thesis - Instituto de Ciências Matemáticas e de Computação, USP. São Carlos/Brasil.

TABOADA, Maite (2006) "Discourse Markers as Signals (or Not) of Rhetorical Relations." Journal of Pragmatics 38/4, 567-592.

TABOADA, Maite (2009) "Implicit and explicit coherence relations." In: J. Renkema (ed), Discourse, of Course. Amsterdam/Philadelphia: John Benjamins. 125-138.

TANNEN, Deborah (1982) Spoken and written language: exploring orality and literacy. Norwood: Ablex.

ThOMPSON, Sandra (1985) "Grammar and written discourse: initial vs. final purpose clause in English.” Text 5, 55-84. 


\section{Abstract \\ COHERENCE RELATIONS IN ACADEMIC SPOKEN DISCOURSE}

According to Rhetorical Structure Theory, implicit propositions emerge from the combination of pieces of text which hang together. Implicit propositions have received various labels as coherence relations, discourse relations, rhetorical relations or relational propositions. When two portions of a text hold a relation, the addressee of the text may recognize the connection even without the presence of a formal sign as a conjunction or a discourse marker. In this paper we claim that some intrinsic spoken discourse phenomena like paraphrasing, repetition, correction and parenthetical insertion hold coherence relations with other portions of discourse and, thus, may be considered strategies for the construction of coherence. The analysis, based on academic spoken discourse (five university lectures in Brazilian Portuguese), shows that these phenomena are recurring and relevant for the study of spoken discourse.

Keywords: spoken discourse, paraphrasing, repetition, correction, parenthetical insertion.

\section{Povzetek KOHERENČNI ODNOSI V AKADEMSKEM GOVORJENEM DISKURZU}

Teorija retorične strukture zagovarja tezo, da iz določenih kombinacij sopostavljenih besedilnih enot vznikajo implicitne propozicije. Implicitne propozicije so dobile različna poimenovanja, kot so koherenčni odnosi, diskurzivni odnosi, retorični odnosi in relacionalne propozicije. Ko je med dvema deloma besedila vzpostavljen odnos, naslovnik besedila prepozna povezavo med njima tudi brez formalnega znaka, kot je na primer veznik ali diskurzni označevalec. V prispevku pokažemo, da lahko nekatere govorne prvine, kot so parafraziranje, ponavljanje, popravljanje in vrinjeni stavek, vzpostavijo koherenčni odnos med besedilimi enotami, zato jih lahko obravnavamo kot strateška sredstva pri ustvarjanju besedilne koherence. Rezultati analize, osnovane na akademskem govorjenem diskurzu (pet predavanj v brazilski portugalščini), potrjujejo pogostost tovrstnih pojavov in utemeljujejo relevantnost tovrstnih raziskav za poznavanje govorjenega jezika.

Ključne besede: govorjeni diskurz, parafraziranje, ponavljanje, popravljanje, vrinjeni stavek. 